\title{
Effect of Talc Addition on the Extraction Yield and Quality of Extra Virgin Olive Oils from Coratina Cultivar after Production and during Storage
}

\author{
Francesco Caponio $^{1 *}$, Julieta I. Monteleone ${ }^{2}$, Giovanni Martellini ${ }^{3}$, Carmine Summo ${ }^{1}$, \\ Vito M. Paradiso ${ }^{1}$ and Antonella Pasqualone ${ }^{1}$ \\ ${ }^{1}$ University of Bari Aldo Moro, Department of Soil, Plant and Food Sciences, Food Science and Technology Unit, Via Amendola, 165/A, I-70126, \\ Bari, Italy \\ ${ }^{2}$ Consejo Nacional de Investigaciones Científicas y Técnicas, Universidad Nacional de Cuyo, Mendoza, Argentina \\ ${ }^{3}$ SVINT - Cooperativa Sviluppo \& Integrazione, Via Vaccaro, 33, I-70121 Bari, Italy
}

\begin{abstract}
An experimental investigation was carried out with the aim to evaluate the effect of talc on the extraction yield and quality of extra virgin olive oils from Coratina olives after production and during storage. A significant effect of talc, added in the malaxer, on both yield and oil quality was observed. The addition of $1 \%$ talc lead to a $15 \%$ decrease of the residual oil in the olive-pomace, while higher amounts of talc did not determine further significant variations. The use of talc caused also a significant decrease of the peroxide value and tocopherols and a significant increase of carotenoids, chlorophylls, phenols, antioxidant activity and $K_{270}$, while no influence was detected on free fatty acids and $K_{232}$. Finally, during storage the differences among the oils were maintained as immediately after their production, with the exception of chlorophylls.
\end{abstract}

Key words: coadjuvant, extra virgin olive oil, oil extraction, storage, talc, yield

\section{INTRODUCTION}

Extra virgin olive oil - a key element in the daily diet of a large part of the Mediterranean population - can be directly consumed after extraction without any further treatment since it is "obtained from the fruit of the olive tree solely by mechanical or other physical means under conditions that do not lead to alteration in the oil, which have not undergone any treatment other than washing, decantation, centrifugation or filtration, to the exclusion of oils obtained using solvents or using adjuvants having a chemical or biochemical action, or by re-esterification process and any mixture with oils of other kinds." ${ }^{1)}$. Its consumption has been related to reduced incidence of coronary heart disease, low blood pressure levels and diabetes ${ }^{2-4)}$. Furthermore, olive oil is characterized by high amounts of monounsaturated fatty acids, as well as high content of antioxidant agents, able to scavenge free radicals and afford an adequate protection against peroxidation ${ }^{5)}$.

The productive process of extra virgin olive oil involves: i) olive crushing, aimed to tear the flesh cells and let the oil run out; ii) olive paste malaxation, to enable the merging of oil droplets into larger drops (coalescence), until they form "pockets" that can be separated into a continuous liquid phase; iii) olive oil separation from the other phases (solid and water phase) by pressure, centrifugation or percolation. However, only $80-90 \%$ of the oil located into the vacuoles of olive pulp cells can be easily extracted: some oil remains inside the unsheltered cells, some is retained by the olive paste colloidal system as microgel, and some remains emulsified with the water phase ${ }^{6)}$. The difficulty of freeing this "bound" oil lies mainly in the fact that the droplets of dispersed or emulsified oil are surrounded by a lipoprotein membrane (phospholipids and proteins) that keeps them in that state $^{7)}$. This phenomenon is more pronounced for the so-called "difficult olive pastes" ${ }^{8)}$, where for "difficult" is intended a low machinability usually due to low ripeness degree, that leads to low yields.

To improve oil yield, several researches have been evaluating the effects of both malaxation phase (time and temperature) and technological coadjuvants (enzymes, salt and talc) which, added at the malaxation step, help to break down water-oil emulsions and consequently make oil ex-

*Correspondence to: Francesco Caponio, Università degli Studi di Bari Aldo Moro, DiSSPA, Sezione di Scienze e Tecnologie Alimentari, Via Amendola 165/a, I-70126 Bari, Italy

E-mail: francesco.caponio@uniba.it

Accepted July 22, 2014 (received for review June 19, 2014)

Journal of Oleo Science ISSN 1345-8957 print / ISSN 1347-3352 online

http://www.jstage.jst.go.jp/browse/jos/ http://mc.manusriptcentral.com/jjocs 
traction easier.

In particular, many authors observed that the increase of malaxation time up to 45-50 min raised the oil extraction yield, whereas longer time (60-75 min) determined a decrease of extraction yield $^{6,10)}$. Also increasing the malaxation temperature generally determines an increase of oil extraction yield ${ }^{6,10)}$, due to a reduction of the oily phase viscosity ${ }^{11)}$, even if malaxing at temperature of $45^{\circ} \mathrm{C}$ caused lower yields, probably due to change in the paste rheology and increased interactions between lipids, proteins, and carbohydrates $^{12)}$. Nevertheless, higher malaxation temperatures could accelerate the oxidative process and loss of both phenolics and volatile compounds, responsible for oil sensory properties, have been reported (although in some cases with controversial results) ${ }^{9,13,14)}$, compromising the nutritional value of extra virgin olive oil.

As regards the use of coadjuvants, the use of common salt $(\mathrm{NaCl})$ as a physical-acting coadjuvant could represent a feasible mean for the improvement of oil extraction ${ }^{15,16)}$. Moreover, different studies proved the efficacy of pectolytic enzymes addition during olive oil extraction to increase yield $^{17,18)}$. However, the oils obtained with the use of enzymes cannot be defined as "virgin" ${ }^{1)}$, because of the biochemical action causing cell wall rupture. The use of talc as coadjuvant during malaxation - not excluded by the same EC regulation due to its exclusively physical action ${ }^{19)}$ - has been proved to increase oil extraction yield for difficult pastes ${ }^{8,19-25)}$. However, almost all the researches until now carried out regard the use of talc on Spanish olive cultivars, whereas few studies have been made for Italian olive cultivars. In particular, Ranalli et al. ${ }^{25)}$ investigating on the effect of pectocellulolytic enzymes and/or talc addition in de-stoned and not-stoned olives from different Italian cultivars (Gentile di Chieti, Caroleo and Coratina) evinced higher nutraceutical value of the obtained oils. Coratina, that represents one of the most diffused Italian cultivars ${ }^{26)}$, gives a difficult paste because it has a rather low maturity index at the time of processing. Moreover, no studies are present in literature regarding the influence of talc addition on the evolution of oil quality indices during storage.

In this framework, the aim of the present research was to evaluate the effect of talc on extraction yield and quality of Coratina oil, both after production and during storage.

\section{MATERIALS AND METHODS}

\subsection{Plant material}

Olive fruits (Olea europaea L.) from Coratina cultivar, mechanically harvested in the first decade of December 2012, were transported immediately after harvesting in a local plant (Andria, Bari, Italy) where, unwashed and after leaf-removal, were milled within $24 \mathrm{~h}$.

\subsection{Oil extraction process}

A lot of about $6,000 \mathrm{~kg}$ of olives was divided into six homogeneous batches: two batches were processed by adding micronized natural talc (hydrated magnesium silicate, Imerys Talc, Luzenac, France) at 1\% level(Ta1); two were added of $2 \%$ talc (Ta2); the last two batches were processed without talc addition ( $\mathrm{C}$, control). Talc was added at the beginning of the malaxation phase.

In particular, each of the six batches was milled for 30 min by means of a 4-stone mill (F.lli Ferri, Andria, Bari, Italy), then the paste was hammer-crushed. The stone mill is constituted by a rough granite base $(3.2 \times 0.3 \mathrm{~m})$ and 4-rough granite wheels $(1.3 \times 0.3 \mathrm{~m})$, whereas all the other parts are in stainless steel. The hammer-crusher (model A40, power 30.75 kW, Amenduni Nicola S.p.A., Modugno, Bari, Italy) operated at 2,800 rpm and was equipped with a grid with holes of $5 \mathrm{~mm}$ of diameter, to break any olives not yet completely crushed. The crushed paste was then transferred into the malaxer (Amenduni Nicola S.p.A., Modugno, Bari, Italy), where it was mixed with talc only for the trials that provided its addition. After malaxation (50 min at $22 \pm$ $1^{\circ} \mathrm{C}$ ) the paste was pumped into a two-phase decanter (Taurus 902-XX, Amenduni Nicola S.p.A., Modugno, Bari, Italy) - operating at 2,800 rpm, with a processing capacity of $3,000 \mathrm{~kg} \mathrm{~h}^{-1}$ - and diluted with $200 \mathrm{~L} \mathrm{~h}^{-1}$ of water. Finally, the oily phase was separated from any aqueous residue by centrifugation at 6,400 rpm (vertical centrifuge, Alfa Laval, Tavarnelle Val di Pesa, Florence, Italy).

Then, the obtained oil was poured into 1-L clear glass bottles, with headspace of about $3 \mathrm{~mL}$, that were hermetically sealed. Three bottles for each batch were sampled. One bottle for each batch was immediately analyzed (T0), whereas the others were placed in a carton box and stored in the dark to be analyzed after three(T3) and six (T6) months of storage. The average storage temperatures were $15^{\circ} \mathrm{C}$ during winter and $25^{\circ} \mathrm{C}$ in the spring.

\subsection{Analytical determinations}

The olive maturity index was determined by a visual evaluation of the color of the olive skin and flesh ${ }^{27)}$. The procedure consisted in distributing 100 olives in eight groups, according to the following characteristics: brightgreen $\operatorname{skin}($ group $\mathrm{N}=0$ ), green-yellowish $\operatorname{skin}($ group $\mathrm{N}=$ 1 ), green skin with reddish spots (group $\mathrm{N}=2$ ), reddishbrown skin (group $\mathrm{N}=3$ ), black skin with white flesh (group $\mathrm{N}=4$ ), black skin with $<50 \%$ purple flesh (group $\mathrm{N}=5$ ), black skin with $50 \%<$ purple flesh $<100 \%$ (group $N=6$ ), and black skin with $100 \%$ purple flesh (group $N=7$ ). The index is given by $\sum\left(\mathrm{N}_{\mathrm{i}} \mathrm{n}_{\mathrm{i}}\right) / 100$, where $\mathrm{N}$ is the group number and $n$ is the olive number in that group. Maturity index values range from 0 to 7 .

The moisture content ( $\% \mathrm{w} / \mathrm{w}$ ) was determined by drying the milled olive at $105^{\circ} \mathrm{C}$ to constant weight ${ }^{28)}$ and the total oil content $(\%$ w/w $)$ was determined by Soxhlet extrac- 


\section{Effect of talc on yield and quality of virgin olive oils}

tion $^{29)}$

The determinations of the free fatty acids (FFA), peroxide value $(\mathrm{PV})$ and spectrophotometric constants were carried out according to the official methods ${ }^{29)}$.

The phenolic compounds of the oils were extracted and purified following the procedure reported by Gambacorta et $a l .^{30)}$ with some modifications. About $1 \mathrm{~g}$ of oil was added with $1 \mathrm{~mL}$ of hexane and $5 \mathrm{~mL}$ of methanol/water $(70: 30 \mathrm{v} /$ v). After $10 \mathrm{~min}$ vortexing, and centrifugation at 9,000 rpm for 10 min (Beckman Coulter, Fullerton, California, USA), the methanol/water phase was recovered and the extraction was repeated twice. The methanol/water phases were pooled, filtered through nylon filters (pore size $0.45 \mu \mathrm{m}$, Sigma, Ireland), and submitted to Folin-Ciocalteu reaction. In particular, an aliquot of the methanol/water solution of phenolic compounds $(100 \mu \mathrm{L})$ was diluted in $6 \mathrm{~mL}$ of water, followed by the addition of $0.5 \mathrm{~mL}$ of Folin-Ciocalteu reagent; the mixture was incubated for 2 min at room temperature, and $2 \mathrm{~mL}$ of sodium carbonate $\left(200 \mathrm{~g} \mathrm{~L}^{-1}\right)$ were added to the reaction mixture, which was finally mixed and diluted with water to $10 \mathrm{~mL}$. The mixture was vortexed for $20 \mathrm{sec}$ and incubated for $60 \mathrm{~min}$ at room temperature in the dark. The absorbance of the sample was read at 750 $\mathrm{nm}$. Results were expressed as mg of gallic acid per $\mathrm{kg}^{-1}$ of oil.

Chlorophylls and total carotenoids were determined as reported in Caponio et $a l^{31}{ }^{31}$. In particular, the chlorophyll content was evaluated by the absorption spectrum of each oil sample, according to the AOCS method ${ }^{32)}$, and expressed as mg of pheophytin a per kg of oil. The concentration of total carotenoids was calculated measuring the absorption of $0.25 \mathrm{~g}$ of oil dissolved in $5 \mathrm{~mL}$ UV-hexane at $449 \mathrm{~nm}$. A calibration curve $\left(y=0.0532 x ; R^{2} 0.9986\right)$ was previously set up by measuring the absorption of solutions of $\beta$-carotene at known concentrations. For all the spectrophotometric determinations a Cary 60 spectrophotometer Agilent (Cernusco, Milan, Italy) (Cernusco, MI, Italy)was used.

Total tocopherols $(\alpha, \beta, \gamma$, and $\delta$ ) were determined by HPLC according to the method reported by Kamal-Eldin et $a l .^{33)}$ with some modifications. Briefly, $950 \mu \mathrm{L}$ of isooctane (containing $2 \mathrm{~g} \mathrm{~L}^{-1}$ of BHT and $1 \mathrm{~g} \mathrm{~L}^{-1}$ of ascorbic acid) were added to about $50 \mathrm{mg}$ of oil. The samples were injected into a HPLC system consisting of a Waters 600E quaternary pump (Milford, MA, USA), a 7725i Rheodyne injector (20- $\mu \mathrm{L}$ sample loop) and a Waters 470 Spectrofluorimeter (excitation wavelength $294 \mathrm{~nm}$, emission wavelength 330 $\mathrm{nm})$. The stationary phase was a YMC-Pack SIL column $(150 \times 4.6 \mathrm{~mm}$ i.d., $5 \mu \mathrm{m}$ particle size $)$; the mobile phase was $n$-hexane-isopropyl alcohol $(99.5: 0.5 \mathrm{v} / \mathrm{v})$ at a flow rate of $1 \mathrm{~mL} \mathrm{~min}{ }^{-1}$. Quantitative analysis was performed by external standard method on the basis of a previously set up calibration curve of $\alpha$-tocopherol $\left(\mathrm{y}=3 \mathrm{E}-05 \mathrm{x}-0.2823 ; \mathrm{R}^{2}=\right.$ $0.9992)$
The antioxidant activity was determined by means of the 2,2-diphenyl-1-picrylhydrazyl (DPPH) stable radical scavenging capacity test, according to the method proposed by Ramadan and Morsel $^{34)}$. In particular, $50 \mu \mathrm{L}$ of oil were dissolved in $500 \mu \mathrm{L}$ of isooctane, the mixture was vortexed for $1 \mathrm{~min}$ and an aliquot of $200 \mu \mathrm{L}$ was let to react in a $1-\mathrm{cm}$ path cuvette at $22^{\circ} \mathrm{C}$ under continuous stirring with $1.8 \mathrm{~mL}$ of a $10^{-4} \mathrm{M}$ isooctane solution of DPPH. The decrease of absorbance at $515 \mathrm{~nm}$ was recorded after 60 minutes against a blank of isooctane using a Cary 60 spectrophotometer Agilent (Cernusco, Milan, Italy). The antioxidant activity was considered as the difference of absorbance between each sample and an isooctane DPPH solution without the sample (control) and was calculated as percentage of inhibition according to the following equation:

$$
\% \text { of inhibition }=\frac{\text { absorbance of control }- \text { absorbance of sample }}{\text { absorbance of control }} \times 100
$$

\subsection{Statistical analysis}

Analysis of variance (one-way and two-way ANOVA) was carried out on the experimental data by the XLStat software (Addinsoft SARL, New York, NY, USA). Two-way ANOVA was performed considering the amount of talc added at the beginning of the malaxation phase (talc) and storage time of the extra virgin olive oils (time), as well as their first order interaction, as independent variables; Tukey's HSD test was applied for multiple comparisons.

\section{RESULTS AND DISCUSSION}

Compositional characteristics and maturity index of the olive lot used for the experiment are given in Table 1 . Moisture and oil content were those normally detected in olives, whose low ripeness degree was evinced by the maturity index.

Table 2 reports moisture level and oil content of the olive-pomace remaining from the trials, as well as the results of one-way ANOVA followed by Tukey HSD test. The addition of talc lead to an increase of the oil extraction yield, as pointed out by the significantly lower residual oil content in the olive-pomaces deriving from the trials involving the use of talc than in control. These results agree with previous studies carried out on other cultivars (such as Picual, Arbequina, Hojiblanca, and Carrasqueña) with different ripening status and composition ${ }^{6,19-23,28,35)}$. When adding talc, the residual oil content of the olive-pomace was significantly lower than in case of control, with a decrease of about $15 \%$. However, no significant difference was observed in the amount of oil in olive-pomaces when varying the amount of talc, confirming the findings of other authors ${ }^{20,35)}$. Finally, no significant differences were found in moisture content of olive-pomace.

Table 3 reports the results of two-way ANOVA with first 
Table 1 Compositional characteristics and ripening index of the processed olives ${ }^{\mathrm{a}}$.

\begin{tabular}{cccc}
\hline Maturity index & Moisture (\%) & Oil (\%) & Solids (\%) \\
\hline 1.2 & 51.54 & 20.01 & 28.45 \\
\hline
\end{tabular}

${ }^{a}$ Means of five replicates: coefficient of variance in all cases $<5 \%$

Table 2 Moisture and oil content of olive-pomace (mean value and standard deviation) and results of oneway ANOVA followed by Tukey HSD test.

\begin{tabular}{lcc}
\hline \multicolumn{1}{r}{ Olive lot } & Moisture (\%) & Oil (\% dry matter) \\
\hline $\mathrm{C}$ & $67.56 \pm 1.60$ & $9.77 \pm 0.26 \mathrm{~A}$ \\
$\mathrm{Ta} 1$ & $66.49 \pm 0.50$ & $8.35 \pm 0.35 \mathrm{~B}$ \\
$\mathrm{Ta} 2$ & $64.77 \pm 0.42$ & $8.49 \pm 0.18 \mathrm{~B}$ \\
$p$-value & 0.144 & 0.024 \\
\hline
\end{tabular}

Olive processed without (C) and with $1 \%$ (Ta1) or $2 \%(\mathrm{Ta} 2)$ of talc added Different letters indicate significant differences at $p<0.05$

Table 3 Results of the analysis of variance (two-way ANOVA with first-order interaction) performed on the analytical data.

\begin{tabular}{lrrrrrrrr}
\hline \multirow{2}{*}{ Determinations } & \multicolumn{2}{c}{ Model } & \multicolumn{2}{c}{ Talc } & \multicolumn{2}{c}{ Time } & \multicolumn{2}{c}{ Talc*time } \\
\cline { 2 - 9 } & \multicolumn{1}{c}{ F } & \multicolumn{1}{c}{$p$-value } & \multicolumn{1}{c}{ F } & p-value & \multicolumn{1}{c}{ F } & p-value & \multicolumn{1}{c}{ F } & $p$-value \\
\hline FFA & 2.25 & 0.125 & 1.044 & 0.391 & 7.190 & 0.014 & 0.379 & 0.818 \\
PV & 2698.14 & $<0.001$ & 535.04 & $<0.001$ & 10209.97 & $<0.001$ & 23.78 & $<0.001$ \\
$\mathrm{~K}_{232}$ & 17.37 & $<0.001$ & 2.79 & 0.114 & 62.67 & $<0.001$ & 2.01 & 0.177 \\
$\mathrm{~K}_{270}$ & 4.98 & 0.014 & 13.55 & 0.002 & 2.25 & 0.161 & 2.09 & 0.168 \\
Phenols & 8.03 & 0.003 & 15.54 & 0.001 & 15.94 & 0.001 & 0.315 & 0.861 \\
Tocopherols & 32.60 & $<0.001$ & 5.12 & 0.033 & 124.19 & $<0.001$ & 0.55 & 0.706 \\
Carotenoids & 31.91 & $<0.001$ & 126.88 & $<0.001$ & 0.64 & 0.549 & 0.05 & 0.994 \\
Chlorophylls & 24.30 & $<0.001$ & 35.30 & $<0.001$ & 47.40 & $<0.001$ & 7.24 & 0.007 \\
Antioxidant activity & 9.75 & $<0.001$ & 37.76 & $<0.001$ & 0.83 & 0.469 & 0.20 & 0.993 \\
\hline
\end{tabular}

FFA, free fatty acids; $\mathrm{PV}$, peroxide value; $\mathrm{K}_{232}$, specific absorption at $232 ; \mathrm{K}_{270}$, specific absorption at $270 \mathrm{~nm}$

order interaction performed on all the chemical and physical analytical data obtained. The ANOVA models resulted to be significant in all cases; talc variable proved to have a significant effect on all the indices except free fatty acids and $\mathrm{K}_{232}$, whereas time variable had not a significant effect only on $\mathrm{K}_{270}$, carotenoids and antioxidant activity. The firstorder interaction talc*time resulted significant only for peroxide value and chlorophylls.

Table 4 reports the results of the analytical parameters (mean values and standard deviations) of the oil obtained both immediately after production and during storage, and the results of two-way ANOVA followed by Tukey HSD test for multiple comparisons. As shown, all the oils obtained belonged to the "extra virgin olive oil" category ${ }^{36)}$.

The use of talc determined a significant decrease of the $\mathrm{PV}$, confirming the findings both of Ben-David et al. ${ }^{37)}$, in oil from cv. Barnea obtained by adding 5.7\% of talc, and Carrapiso et $a l .^{23)}$. Other authors ${ }^{20-22,28)}$ reported that talc produces only a physical action on oil, with no influence on the quality indexes prescribed by current Regulations. Fernández Valdivia et $a l .^{22)}$, considering cv. Hojiblanca, reported that talc addition protects the oil from oxidation during extraction, while Cruz et al. ${ }^{15)}$ observed in several cultivars that talc addition tended to increase oil stability. Moreover, talc addition did not significantly influence FFA and $\mathrm{K}_{232}$, as found by Carrapiso et $a{ }^{23)}$ and Moya et al. ${ }^{28)}$, whereas $\mathrm{K}_{270}$ significantly increased, although Cert et al. ${ }^{19}{ }^{\prime}$ and Carrapiso et $a{ }^{23}{ }^{23}$ did not found significant variation. These results show that talc does not exert any alteration on the oil quality parameters prescribed by the EEC official method n. 2568/91 ${ }^{29)}$ and successive amendments.

As regards the other analytical parameters, the use of 
Table 4 Results of the analytical parameters (mean values and standard deviations) of the oil obtained both immediately after production and during storage, and the results of Tukey HSD test for multiple comparisons.

\begin{tabular}{|c|c|c|c|c|c|c|c|c|}
\hline \multirow{2}{*}{$\begin{array}{r}\text { Parameter } \\
\text { FFA }\left({\left.\mathrm{g} 100 \mathrm{~g}^{-1}\right)}^{-1}\right.\end{array}$} & \multicolumn{2}{|c|}{ Talc } & \multirow{2}{*}{$\frac{\mathrm{T} 0}{0.18 \pm 0.02}$} & \multirow[b]{2}{*}{$\mathrm{a}$} & \multicolumn{2}{|l|}{ T3 } & \multicolumn{2}{|l|}{$\mathrm{T} 6$} \\
\hline & $\mathrm{C}$ & $\mathrm{A}$ & & & $0.21 \pm 0.02$ & $\mathrm{a}$ & $0.20 \pm 0.02$ & $\mathrm{a}$ \\
\hline & Ta1 & A & $0.18 \pm 0.02$ & $\mathrm{a}$ & $0.23 \pm 0.01$ & $\mathrm{a}$ & $0.22 \pm 0.01$ & $\mathrm{a}$ \\
\hline & $\mathrm{Ta} 2$ & $\mathrm{~A}$ & $0.18 \pm 0.02$ & $\mathrm{a}$ & $0.23 \pm 0.01$ & $\mathrm{a}$ & $0.23 \pm 0.03$ & $\mathrm{a}$ \\
\hline \multirow[t]{3}{*}{$\mathrm{PV}\left(\right.$ meq $\mathrm{O}_{2} \mathrm{~kg}^{-1}$ ) } & $\mathrm{C}$ & $\mathrm{A}$ & $2.33 \pm 0.01$ & $\mathrm{e}$ & $6.63 \pm 0.01$ & $\mathrm{a}$ & $6.62 \pm 0.01$ & $\mathrm{a}$ \\
\hline & Ta1 & $\mathrm{C}$ & $1.66 \pm 0.01$ & $\mathrm{~g}$ & $5.32 \pm 0.01$ & $\mathrm{~d}$ & $5.55 \pm 0.35$ & $\mathrm{c}$ \\
\hline & $\mathrm{Ta} 2$ & $\mathrm{~B}$ & $1.99 \pm 0.01$ & $\mathrm{f}$ & $5.63 \pm 0.04$ & $\mathrm{bc}$ & $5.82 \pm 0.02$ & $\mathrm{~b}$ \\
\hline \multirow[t]{3}{*}{$\mathrm{K}_{232}$} & $\mathrm{C}$ & A & $1.579 \pm 0.036$ & $\mathrm{~b}$ & $1.886 \pm 0.040$ & $\mathrm{a}$ & $1.914 \pm 0.069$ & $\mathrm{a}$ \\
\hline & Ta1 & $\mathrm{A}$ & $1.643 \pm 0.098$ & $\mathrm{~b}$ & $1.941 \pm 0.007$ & $\mathrm{a}$ & $1.893 \pm 0.077$ & $\mathrm{a}$ \\
\hline & $\mathrm{Ta} 2$ & A & $1.638 \pm 0.056$ & $\mathrm{~b}$ & $1.906 \pm 0.004$ & $\mathrm{a}$ & $2.065 \pm 0.049$ & $\mathrm{a}$ \\
\hline \multirow[t]{3}{*}{$\mathrm{K}_{270}$} & $\mathrm{C}$ & B & $0.145 \pm 0.013$ & $\mathrm{~b}$ & $0.146 \pm 0.010$ & $\mathrm{~b}$ & $0.135 \pm 0.007$ & $\mathrm{~b}$ \\
\hline & Ta1 & $\mathrm{A}$ & $0.158 \pm 0.001$ & $\mathrm{ab}$ & $0.160 \pm 0.007$ & $\mathrm{ab}$ & $0.179 \pm 0.010$ & $\mathrm{ab}$ \\
\hline & $\mathrm{Ta} 2$ & $\mathrm{~A}$ & $0.169 \pm 0.003$ & $\mathrm{ab}$ & $0.165 \pm 0.001$ & $a b$ & $0.194 \pm 0.027$ & $\mathrm{a}$ \\
\hline \multirow[t]{3}{*}{ Phenols ( $\mathrm{m} \mathrm{kg}^{-1}$ ) } & $\mathrm{C}$ & $\mathrm{B}$ & $606 \pm 42$ & $a b c$ & $488 \pm 44$ & $\mathrm{c}$ & $504 \pm 49$ & $\mathrm{c}$ \\
\hline & Ta1 & $\mathrm{A}$ & $764 \pm 39$ & a & $633 \pm 54$ & $a b c$ & $604 \pm 19$ & $a b c$ \\
\hline & $\mathrm{Ta} 2$ & $\mathrm{~A}$ & $710 \pm 54$ & $\mathrm{ab}$ & $612 \pm 42$ & $a b c$ & $583 \pm 41$ & $\mathrm{bc}$ \\
\hline \multirow[t]{3}{*}{ Tocopherols $\left(\mathrm{mg} \mathrm{kg}^{-1}\right)$} & $\mathrm{C}$ & $\mathrm{A}$ & $226.72 \pm 15.76$ & $\mathrm{a}$ & $211.20 \pm 2.69$ & $\mathrm{a}$ & $128.29 \pm 16.52$ & $\mathrm{~b}$ \\
\hline & Ta1 & $\mathrm{AB}$ & $221.37 \pm 20.00$ & $\mathrm{a}$ & $205.86 \pm 1.77$ & $\mathrm{a}$ & $114.85 \pm 9.18$ & $\mathrm{~b}$ \\
\hline & $\mathrm{Ta} 2$ & $\mathrm{~B}$ & $195.99 \pm 10.54$ & $\mathrm{a}$ & $194.49 \pm 1.62$ & $\mathrm{a}$ & $112.11 \pm 8.90$ & $\mathrm{~b}$ \\
\hline \multirow[t]{3}{*}{ Carotenoids ( $\mathrm{mg} \mathrm{kg}^{-1}$ ) } & $\mathrm{C}$ & B & $2.94 \pm 0.08$ & $\mathrm{~b}$ & $3.30 \pm 0.34$ & $\mathrm{~b}$ & $3.21 \pm 0.48$ & $\mathrm{~b}$ \\
\hline & Ta1 & A & $6.21 \pm 0.22$ & $\mathrm{a}$ & $5.99 \pm 0.32$ & $\mathrm{a}$ & $5.84 \pm 0.40$ & $\mathrm{a}$ \\
\hline & $\mathrm{Ta} 2$ & $\mathrm{~A}$ & $6.33 \pm 0.09$ & $\mathrm{a}$ & $6.26 \pm 0.36$ & $\mathrm{a}$ & $6.15 \pm 0.42$ & $\mathrm{a}$ \\
\hline \multirow[t]{3}{*}{ Chlorophylls ( $\mathrm{mg} \mathrm{kg}^{-1}$ ) } & $\mathrm{C}$ & $\mathrm{B}$ & $12.33 \pm 0.11$ & $\mathrm{~b}$ & $11.95 \pm 0.08$ & $\mathrm{~b}$ & $11.88 \pm 0.05$ & $\mathrm{~b}$ \\
\hline & Ta1 & A & $14.72 \pm 0.61$ & $\mathrm{a}$ & $12.89 \pm 0.15$ & $\mathrm{~b}$ & $13.05 \pm 0.41$ & $\mathrm{~b}$ \\
\hline & $\mathrm{Ta} 2$ & $\mathrm{~A}$ & $14.64 \pm 0.09$ & $\mathrm{a}$ & $12.39 \pm 0.22$ & $\mathrm{~b}$ & $12.07 \pm 0.49$ & $\mathrm{~b}$ \\
\hline \multirow[t]{3}{*}{ Antioxidant activity * } & $\mathrm{C}$ & $\mathrm{C}$ & $56.29 \pm 0.67$ & $\mathrm{~b}$ & $53.87 \pm 1.95$ & $\mathrm{~b}$ & $53.24 \pm 3.39$ & $\mathrm{~b}$ \\
\hline & Ta1 & A & $73.86 \pm 2.35$ & $\mathrm{a}$ & $70.90 \pm 5.31$ & $\mathrm{a}$ & $69.81 \pm 4.70$ & $\mathrm{a}$ \\
\hline & $\mathrm{Ta} 2$ & $\mathrm{~B}$ & $63.20 \pm 1.83$ & $\mathrm{ab}$ & $63.49 \pm 3.58$ & $\mathrm{ab}$ & $62.90 \pm 4.02$ & $a b$ \\
\hline
\end{tabular}

Olives processed without (C) and with $1 \%$ (Ta1) or $2 \%(\mathrm{Ta} 2)$ of talc added. Oils analyzed after production (T0) and during storage after three (T3) and six (T6) months. FFA, free fatty acids; PV, peroxide value; $\mathrm{K}_{232}$, specific absorption at $232 ; \mathrm{K}_{270}$, specific absorption at $270 \mathrm{~nm}$.

* Calculated as percentage of inhibition. Uppercase letters were used to compare the samples considering the effect of talc, lowercase letters were used to compare the samples considering the combined effect of talc, storage time (months) and talc $\mathrm{x}$ time interaction: different letters indicate significant differences at $p<0.05$

talc caused a significant increase of total phenols, chlorophylls and carotenoids, probably due to the lower amount of water in the olive paste subjected to extraction, ascribable to the hygroscopic effect of talc. In any case, Moya et $a l{ }^{28)}$ reported that the use of talc does not produce any significant variation on the amount of photosynthetic pigments (chlorophylls and carotenoids) - as found also by Fernández Valdivia et $a l .{ }^{22)}$ and Ranalli et $a{ }^{25)}$ - and polyphenols. Also Carrapiso et $a l^{23)}$ and Ranalli et $a l{ }^{25)}$ did not observe any significant influence of talc addition on total phenol content; on the contrary Uceda et $a l .^{21)}$ reported higher phenol contents in oils when talc was used. Moreover, the talc addition caused a significant decrease of tocopherols only when $2 \%$ talc was used. Also Carrapiso et $a l{ }^{23)}$ found a significant decrease of $\alpha$-tocopherol whereas Ranalli et $a l .^{24,25)}$ did not find any substantial variation in the amounts of tocopherols in oils obtained from destoned olives by addition of talc. Up to now, the effect of talc addi- 
tion on tocopherol content has been scarcely studied, and it seems to depend on the cultivar ${ }^{37}$. Finally, the addition of talc determined a significant increase of the antioxidant activity, measured by the DPPH method, more evident when $1 \%$ talc was used. This result is correlated with the content of total phenols obtained in the different trials, and agrees with previous findings ${ }^{38)}$ that highlighted a significant correlation between total phenols and induction time, being the latter related to the total antioxidant compounds of the oil.

As regards the evolution of analytical data during storage, the differences among the oils (Ta1, Ta2 and C) were maintained as immediately after their production. The only exceptions were represented by chlorophylls that at the beginning were significantly lower in control than in trials with talc, but from 3 months onwards did not show statistical difference anymore - and by PV that increased significantly at T3, due to the oxidation of triglycerides provoked by oxygen dissolved in the oil.

As the storage proceeded, primary oxidation increased in the oils (as shown by the trend PV and $\mathrm{K}_{232}$ ), while antioxidant compounds decreased. On the whole, the evolution of the oils during storage confirmed the findings reported by us and by other authors ${ }^{31,39,40)}$. The significant decrease of chlorophylls after three months of storage in oils obtained adding talc during malaxation needs further investigation, involving also the analysis of chlorophylls degradation products. About the significant decrease of tocopherols after six months of storage - confirmed by other findings ${ }^{40,41}$ - it could be due to the protective effect of $\alpha$-tocopherol, the most representative isomer, against oil oxidation, when oxidation takes place under non-accelerated conditions ${ }^{42)}$.

\section{CONCLUSIONS}

The obtained data pointed out a significant effect of talc on the extraction yield and on the quality of the oils obtained from olives of cv. Coratina, that represent one of the most influential Mediterranean olive oil varieties. In particular, the amount of residual oil in the olive-pomace decreased of about $15 \%$, while the oils obtained presented lower oxidation levels and higher amounts of chlorophylls and antioxidants than the corresponding oils obtained without talc addition. Finally, no effect of talc was observed during oil storage, with the exception of chlorophylls and PV.

Further studies are needed in order to evaluate the addition of technological coadjuvants on olives at different ripeness degree.

\section{ACKNOWLEDGMENTS}

Authors want to express their gratitude and acknowledgment to "Oleificio Cooperativo della Riforma Fondiaria di Andria" for technical assistance and for its contribution to the development of this research.

\section{References}

1) Official Journal of the European Communities, European Community Regulation No. 1513/2001, L. 201 of July $26^{\text {th }}$, Publications Office of the European Union, Bruxelles (2001).

2) Psaltopoulou, T.; Naska, A.; Orfanos, P.; Trichopoulos, D.; Mountokalakis, T.; Trichopoulou, A. Olive oil, the Mediterranean diet, and arterial blood pressure: the Greek European Prospective Investigation into Cancer and Nutrition(EPIC) study. Am. J. Clin. Nutr. 80, 1012-1018 (2004).

3) Bendinelli, B.; Masala, G.; Saieva, C.; Salvini, S.; Calonico, C.; Sacerdote, C.; et al. Fruit, vegetables, and olive oil and risk of coronary heart disease in Italian women: the EPICOR Study. Am. J. Clin. Nutr. 93, 275-283 (2011).

4) Salas-Salvadó, J.; Bulló, M.; Babio, N.; MartínezGonzález, M. A.; Ibarrola-Jurado, N.; Basora, J.; et al. Reduction in the incidence of type 2 diabetes with the Mediterranean diet: results of the PREDIMED-Reus nutrition intervention randomized trial. Diabetes Care 34, 14-19 (2011).

5) Visioli, F.; Poli, A.; Galli, C. Antioxidant and other biological activities of phenols from olives and olive oil. Med. Res. Rev. 22, 65-75 (2002).

6) Aguilera, M. P.; Beltran, G.; Sanchez-Villasclaras, S.; Uceda, M.; Jimenez, A. Kneading olive paste from unripe 'Picual' fruits: I. Effect on oil process yield. $J$. Food Eng. 97 533-538(2010).

7) Boskou, D. Olive Oil: Chemistry and Technology. AOCS Press, Champaign, IL (1996).

8) Di Giovacchino, L. L'impiego del talco micronizzato nell'estrazione dell'olio dalle olive con il sistema continuo. Riv. Ital. Sostanze Grasse 65, 623-628(1988).

9) Stefanoudaki, E.; Koutsaftakis, A.; Harwood, J. L. Influence of malaxation conditions on characteristic qualities of olive oil. Food Chem. 127, 1481-1486 (2011).

10) Amirante, R.; Cini, E.; Montel, G. L.; Pasqualone, A. Influence of mixing and extraction parameters on virgin olive oil quality. Grasas y Aceites 52, 198-201(2001).

11) Ranalli, A.; Contento, S.; Schiavone, C.; Simone, N. Malaxing temperature affects volatile and phenol composition as well as other analytical features of virgin olive oil. Eur. J. Lipid Sci. Technol. 103, 228-238 (2001). 


\section{Effect of talc on yield and quality of virgin olive oils}

12) Kalua, C. M.; Bedgood Jr, D. R.; Bishop, A. G.; Prenzler, P. D. Changes in volatile and phenolic compounds with malaxation time and temperature during virgin olive oil production. J. Agric. Food Chem. 54, 76417651 (2006).

13) Boselli, E.; Di Lecce, G. ; Strabbioli, R. ; Pieralisi, G. ; Frega, N. G. Are virgin olive oils obtained below $27^{\circ} \mathrm{C}$ better than those produced at higher temperatures? LWT-Food Sci. Technol. 42, 748-757 (2009).

14) Servili, M.; Selvaggini, R.; Taticchi, A.; Esposto, S.; Montedoro, G. F. Volatile compounds and phenolic composition of virgin olive oil: optimization of temperature and time exposure of olive pastes to air contact during the mechanical extraction process. J. Agric. Food Chem. 51, 7980-7988(2003).

15) Cruz, S.; Yousfi, K.; Pérez, A. G.; Mariscal, C.; García, J. M. Salt improves physical extraction of olive oil. Eur. Food Res. Tech. 225, 359-365 (2007).

16) Pérez, A. G.; Romero, C.; Yousfi, K.; García, J. M. Modulation of olive oil quality using $\mathrm{NaCl}$ as extraction coadjuvant. J. Am. Oil Chem. Soc. 85, 685-691 (2008).

17) Najafian, L.; Ghodsvali, A.; Haddad Khodaparast, M. H.; Diosady, L. L. Aqueous extraction of virgin olive oil using industrial enzymes. Food Res. Int. 42, 171-175 (2009).

18) Ranalli, A.; Pollastri, L.; Contento, S.; Lucera, L.; Del Re, P. Enhancing the quality in virgin olive oil by use of a new vegetable enzyme extract during processing. Eur. Food Res. Tech. 216, 109-115 (2003).

19) Cert, A.; Alba, J.; León-Camacho, M.; Moreda, W.; Pérez-Camino, M. C. Effects of talc addition and operating mode on the quality and oxidative stability of virgin oils obtained by centrifugation. J. Agric. Food Chem. 44, 3930-3934(1996).

20) Hermoso, M.; Uceda, M.; Garcia-Ortiz, A.; Morales, J.; Frías, L.; Fernandez, A. Elaboración de aceite de oliva de calidad. Obtención por el sistema de dos fases. Junta de Andalucia, Seville. Informaciones Técnicas 61/98(1998).

21) Uceda, M.; Jiménez, A.; Beltrán, G. Olive oil extraction and quality. Grasas y Aceites 57, 25-31 (2006).

22) Fernández, D. G.; Espínola, F.; Moya, M. Influencia de diferentes coadyuvantes tecnológicos en la calidad y rendimiento del aceite de oliva virgen utilizando la metodología de superficies de respuesta. Grasas y Aceites 59, 39-44 (2008).

23) Carrapiso, A. I.; García, A.; Petrón, M. J.; Martín, L. Effect of talc and water addition on olive oil quality and antioxidants. Eur. J. Lipid Sci. Technol. 115, 583538(2013).

24) Ranalli, A.; Marchegiani, D.; Pardi, D.; Contento, S.; Pardi, D.; Girardi, F.; Kotti, F. Evaluation of functional phytochemicals in destoned virgin olive oil. Food Bioprocess Technol. 2, 322-327(2009).
25) Ranalli, A.; Benzi, M.; Gomes, T.; Delcuratolo, D.; Marchegiani, D.; Lucera, L. Concentration of natural pigments and other bioactive components in pulp oils from de-stoned olives. Innov. Food Sci. Emerg. Technol. 8, 437-442 (2007).

26) Vossen, P. Olive oil: history, production, and characteristics of the world's classic oils. Hort. Sci. 42, $1093-$ 1100 (2007).

27) Uceda, M.; Frías L. Harvest dates: evolution of the fruit oil content, oil composition and oil quality. In Proceedings of the Second International Meeting of Olive Oil, Córdoba, pp. 125-128(1975).

28) Moya, M.; Espínola, F.; Fernández, D. G.; de Torres, A.; Marcos, J.; Josue, J.; et al. Industrial trials on coadjuvants for olive oil extraction. J. Food Eng. 97, 57-63 (2010).

29) Official Journal of the European Communities. European Community Regulation No. 2568/1991, N. L. 248 of September $5^{\text {th }}$, Publications Office of the European Union, Bruxelles (1991).

30) Gambacorta, G.; Faccia, M.; Previtali, M. A.; Pati, S.; La Notte, E.; Baiano, A. Effects of olive maturation and stoning on quality indices and antioxidant content of extra virgin oils (cv. Coratina) during storage. J. Food Sci. 75, 229-235 (2010).

31) Caponio, F.; Bilancia, M. T.; Pasqualone, A.; Sikorska, E.; Gomes, T. Influence of the exposure to light on extra virgin olive oil quality during storage. Eur. Food Res. Tech. 221, 92-98(2005).

32) AOCS Method Cc 13i-96. Determination of chlorophyll pigments in crude vegetable oils. In Official methods and recommended practices of the American Oil Chemistry Society (Firestone, D. ed) $4^{\text {th }}$ edn., AOCS Press, Washington, DC (1993).

33) Kamal-Eldin, A.; Görgen, S.; Pettersson, J.; Maija Lampi, A. Normal-phase high-performance liquid chromatography of tocopherols and tocotrienols. Comparison of different chromatographic columns. J. Chromatogr. A 881, 217-227(2000).

34) Ramadan, M. F.; Morsel, J. Screening of the antiradical action of vegetable oils. J. Food Compos. Anal. 19, 838-842 (2006).

35) Espínola, F.; Moya, M.; Fernández, D. G.; Castro, E. Improved extraction of virgin olive oil using calcium carbonate as coadjuvant extractant. J. Food Eng. 92, 112-118(2009).

36) Official Journal of the European Communities, European Union Regulation No. 61/2011, N. L. 23 of January $24^{\text {th }}$, Publications Office of the European Union, Bruxelles (2011).

37) Ben-David, E.; Kerem, Z.; Zipori, I.; Weissbein, S.; Basheer, L.; Bustan, A.; Dag, A. Optimization of the Abencor system to extract olive oil from irrigated orchards. Eur. J. Lipid Sci. Technol. 112, 1158-1165 
(2010).

38) Caponio, F.; Alloggio, V.; Gomes, T. Phenolic compounds of virgin olive oil: influence of paste preparation techniques. Food Chem. 64, 203-209 (1999).

39） Morelló, J. R.; Motilva, M. J.; Tovar, M. J.; Romero, M. P. Changes in commercial virgin olive oil (cv Arbequina) during storage, with special emphasis on the phenolic fraction. Food Chem. 85, 357-364(2004).

40) Gómez-Alonso, S.; Mancebo-Campos, V.; Desamparados Salvador, M.; Fregapane, G. Evolution of major and minor components and oxidation indices of virgin olive oil during 21 months storage at room temperature. Food Chem. 100, 36-42 (2007).

41) Del Caro, A.; Vacca, V.; Poiana, M.; Fenu, P.; Piga, A. Influence of technology, storage and exposure on components of extra virgin olive oil (Bosana cv) from whole and de-stoned fruits. Food Chem. 98, 311-316 (2006).

42) Baldioli, M.; Servili, M.; Perretti, G.; Montedoro, G. F. Anti-oxidant activity of tocopherols and phenolic compounds of virgin olive oil. J. Am. Oil Chem. Soc. 73, 1589-1593 (1996). 